\title{
J. Eftekhar-nezhad of Iran
}

Unlike many of us who fear or stand in awe of the desert, J. Eftekhar-nezhad, Vice President of IUGS, loves it with a fervent passion.

"For me the desert conjures up the best of memories. It was my main field of professional experience ... I learned most of my geology not in the laboratory or the university, but out in the desert, in the rough mountainous areas of NW Iran and in the arid parts of central Iran - my favourite area. People in the desert are honest and generous even though they are so very poor. Any work that is done in the desert helps their lot - and that gave me great personal satisfaction."

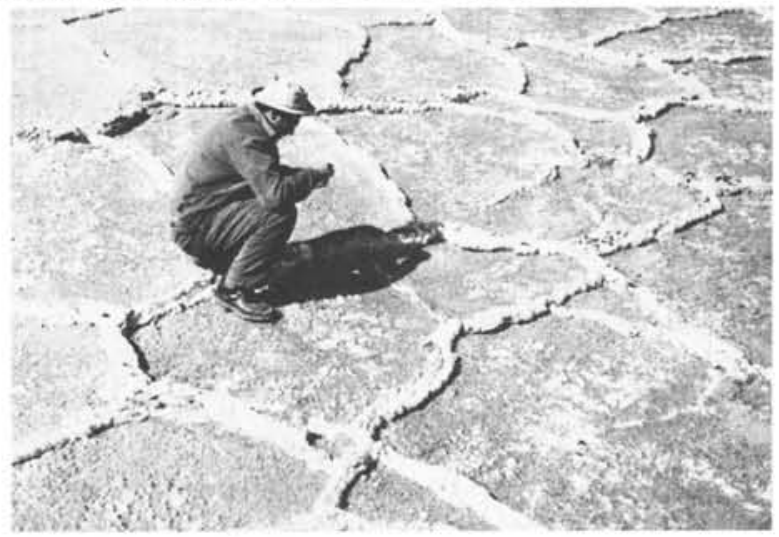

Vice President J. Eftekhar-nezhad studies salt cracks in the Central Desert of Iran - locally called 'Kavir'.

Years ago, Dr. Eftekhar-nezhad (affectionately referred in IUGS circles as "Eftekhar") used to spend up to six adventurous months at a stretch in the desert carrying out geological mapping assignments. Now, as Deputy Managing Director of the Geological Survey of Iran, he can no longer afford the time personally, though he is well aware of the need in his country for an integrated and comprehensive program consisting of more detailed geological mapping (covering all of Iran), prospecting for minerals and geochemical sampling.

Planning and implementing such a program and developing the Survey into a full-fledged research centre, with ongoing research studies into ophiolite problems, clay minerals, seismic methods and tectonic theories, have preoccupied his interests over the last few years.

He speaks with pride of the Survey's advances in its two decades of existence: the whole country has now been mapped at a scale of 1:250 000, aeromagnetic mapping has covered at least $30 \%$ of Iran with geological maps at a scale of 1:100 000 and most of these are published, some 500 people staff the Survey and this includes about 125 scientists in a variety of specializations, and in-house training programs are now flourishing. In short, the Survey is spearheading the development of the science in Iran, which Eftekhar estimates currently boasts some 1,500 geologists.

$\mathrm{He}$ joined the Survey after receiving his doctorate in field geology and tectonics from Tehran University twenty years ago. His subsequent research work spanned the fields of plate tectonics, stratigraphy and economic geology, and included a year of training and field work (under a UN

EPISODES, Vol. 1980, No. 2

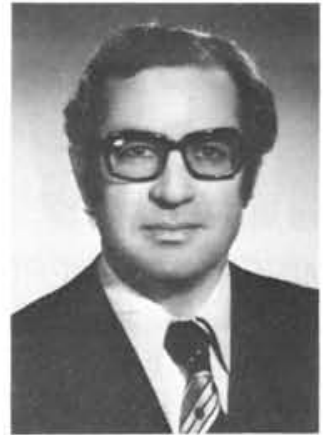

fellowship) in Australia in 1967 which led to the publication of a report on the geology of the Australian Drummond basin (1967). Most of his publications, however, pertain to Iran, including about two dozen detailed maps with explanatory texts or geological reports, a dozen published articles or reports in Persian, as well as some 50 unpublished geological reports.

Eftekhar regards scientific research as his first love, and has continued to lecture, on a part-time basis, at the Institute of Technology in Tabriz and more recently, at the National University of Iran in Tehran. He is an active member of the National Society of Iranian Petroleum, whose membership consists primarily of oil companies, and serves on the Society's Editorial Board and its Committee for Geology.

$\mathrm{He}$ is also on the planning committee of a bilateral multidisciplinary project with the German National Science Foundation carrying out geological and geophysical investigations along a $100 \mathrm{~km}$ wide section in NE Iran from the U.S.S.R. border through to the Persian Gulf. He speaks enthusiastically of another joint research program on tectonics being conducted in a critical part of Iran - the Zagros Mountains near the Turkish border - this time with a group of French researchers.

$\mathrm{He}$ has always enjoyed participating in international programs, particularly in the ICG Working Group 6 (Geodynamics of the Alpine-Himalayan Region, East) and in the Working Group for the Geological Map of Europe and the Mediterranean. He has served on the National Committee for IGCP and also as President of the National Committee for Geodynamics. He looks upon his four-year service to IUGS as a privilege and an honour, and his decision not to serve for a second term as Vice President was made with great personal regret: "My country is facing many challenges at present, and my responsibilities are such that they require my full-time attention."

Eftekhar's calm judgment and gracious goodwill have earned the respect of the Executive and will be missed by the other committee members. But one can appreciate that his keen sense of duty must stem from his very roots: "My background is pure Iranian: 'Eftekhar' is a common name, but 'nezhad' (the ending) is rare - it means 'proud'. And I must admit, I am very proud to be Iranian."

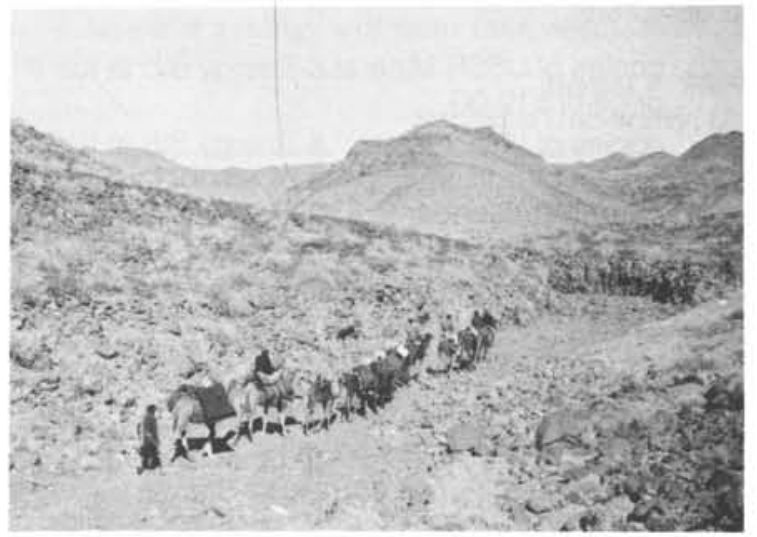

Eftekhar leads an expedition into spectacular Baluchestan, Iran. 
MINERAL \& ENERGY RESOURCES OF THE USSR: A

SELECTED BIBLIOGRAPHY OF SOURCES IN

\section{ENGLISH}

Contains over 1400 references from volumes $1-18$ of INTERNATIONAL GEOLOGY REVIEW plus other English sources. The references are listed under approximately 200 categories, such as Absolute Age, Chromite, Diamond Deposits, Metallogeny, Oil Shale, and Tungsten Deposits. Indexed geographically and by author.

93 pages. $\$ 10$.

Special discount price to subscribers of INTERNATIONAL GEOLOGY REVIEW: $\$ 5$.

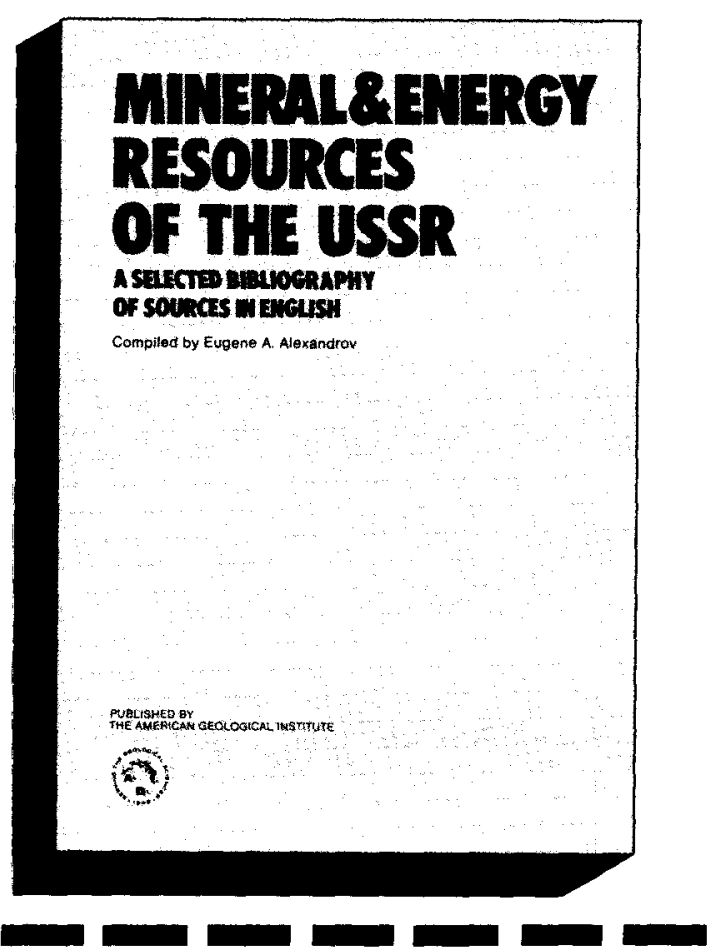

American Geological Institute

Publications Department, One Skyline Place

5205 Leesburg Pike, Falls Church, Virginia 22041

PLEASE SEND ME

copies of USSR Mineral \& Energy Bib at full price of $\$ 10.00$

copies of USSR Mineral \& Energy Bib at IGR subscriber discount price of $\$ 5.00$. I am a current subscriber to IGR and my ID\# (top line of mailing label) is

subscriptions to International Geology Review at $\$ 300$ per year.

I enclose $\$ \_$___ (US\$ or UNESCO coupons).

Invoice needed; Purchase Order No.

AGI Publications List requested.

Ship to: Name

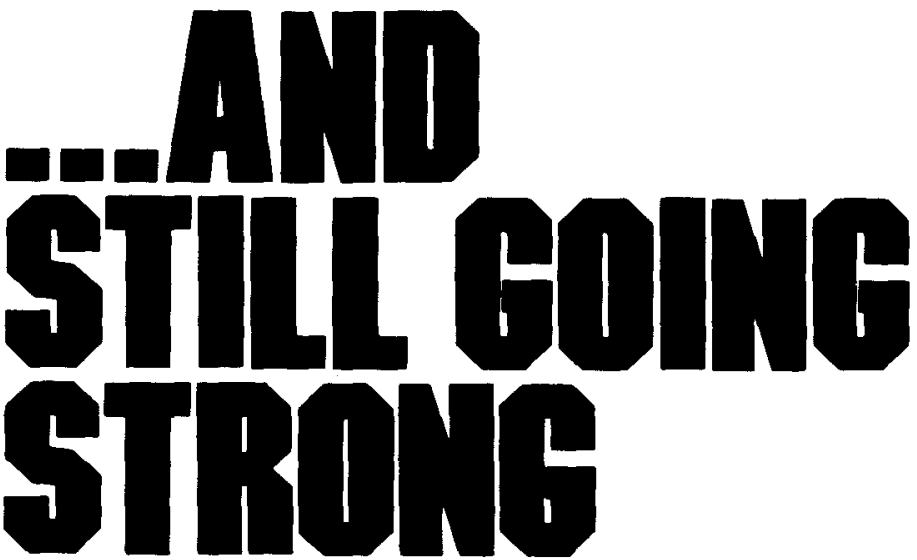

Now in its 22nd year, INTERNATIONAL GEOLOGY REVIEW continues to scan, select, translate, and publish the best and latest research in all Earth Science disciplines from the Soviet and world geological literature in each monthly issue for English-reading geologists thoughout the world. Annual subject and author indexes.

12 issues per year USA $\$ 300$.

Non-USA \$308.

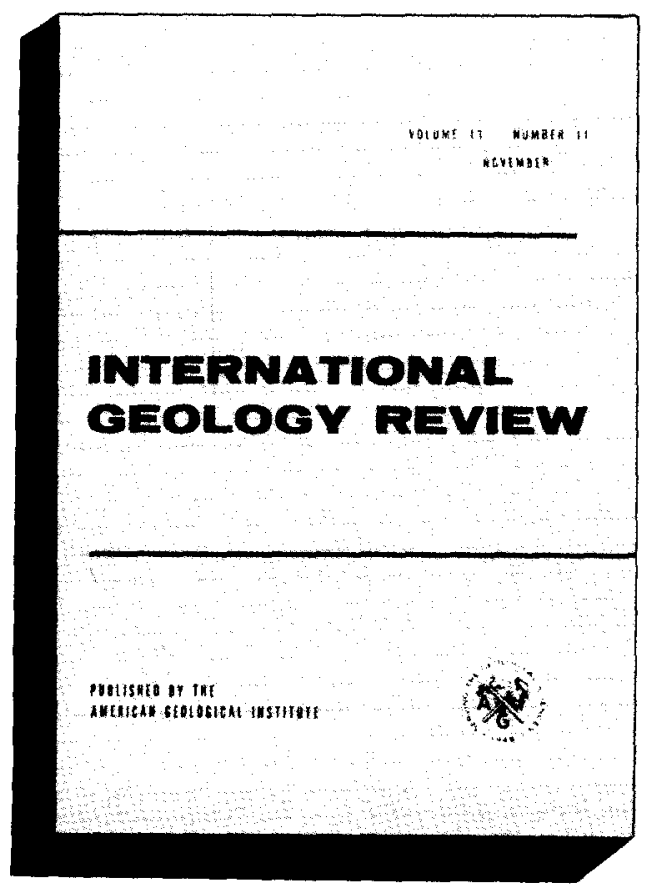

